\title{
The role of $\mathrm{BCL9}$ genetic variation as a biomarker for hepatitis C-related hepatocellular carcinoma in Egyptian patients
}

\author{
Eman Abd El Razek Abbas ${ }^{1}$, Ahmed Barakat Barakat ${ }^{2}$, Mohamed Hassany ${ }^{3}$ and Samar Samir Youssef ${ }^{*}$ (D)
}

\begin{abstract}
Background: Hepatocellular carcinoma (HCC) is considered one of the most common cancers related to mortality around the world, and susceptibility is related with genetic, lifestyle, and environmental factors. Copy number variation of the Bcell CLL/lymphoma 9 (BCL9) gene is a type of structural variation which can influence gene expression and can be related with specific phenotypes and diseases and has a role in hepatocarcinogenesis. Our aims were to assess the copy number variation (CNV) in the BCL9 gene and explore its role in HCV-related HCC Egyptian patients. A total of 50 HCV-related HCC patients were enrolled in the study (including 25 early HCC and 25 late HCC cases); the copy number of the BCL9 gene was detected using quantitative polymerase reaction.

Results: There was a highly statistically significant difference between the two groups (early and late HCC patients) in gender, bilharziasis, performance status, child score class, child grade, focal lesion size, portal vein, and ascites. CNV was detected and represented by the gain in the BCL9 gene in 14\% of patients, and all of them were males. Also, it was noticed that the ratio of gain in BCL9 copy number in late individuals was about 1.5 times than that in early HCC individuals. Moreover, our results showed that the distribution of performance status $>1$, average and enlarged liver, focal lesion size, thrombosed portal vein, and AFP was higher in patients with BCL9 copy number gain.
\end{abstract}

Conclusion: We detected about 14\% gain in BCL9 copy number in Egyptian HCC patients. But the variation in copy number of the BCL9 gene did not affect HCC development in our patients' cohort.

Keywords: Hepatocellular carcinoma, BCL9, Copy number variation, Circulating free DNA, Biomarker

\section{Background}

Hepatocellular carcinoma (HCC) is one of the most universal problems worldwide, it is the 6th most common cancer and the 4th cause of cancer-related death all over the world. There is variation in the predominance of HCC in the epidemiological data from one place to another [ 1 , 2]. In Egypt, HCC ranks the 4th common cancer, and it is considered the most reason for mortality- and morbidityassociated cancer [3, 4].

\footnotetext{
*Correspondence: samaryoussef67@gmail.com; ss.youssef@nrc.sci.eg ${ }^{1}$ Microbial Biotechnology Department, National Research Centre, 33 El-Buhouth St., Dokki, Giza, Cairo 12622, Egypt

Full list of author information is available at the end of the article
}

There are many risk factors in HCC development, which include [1] environmental factors such as hepatitis $B$ virus (HBV) and hepatitis $\mathrm{C}$ virus (HCV) infection, chemical compounds, alcohol, and smoking [2]; hostrelated risk factors such as gender, ethnicity, obesity, autoimmune hepatitis, diabetes, and non-alcoholic fatty liver disease (NAFLD) [3]; genetic-related factors such as the history of HCC, aflatoxins, and genetic alterations [5]. Both HBV and HCV increase HCC risk by 20 -fold [6-8]. In Egypt, $\mathrm{HCV}$ is the most critical risk factor in liver cancer including HCC; about $21.4 \%$ of HCC individuals have a family history of HCC $[9,10]$.

Although the survival rate is approximately 5 years, this rate is estimated to be $18 \%$, and the median survival is only 7 months, if untreated [11-14]. HCC patients are 
often diagnosed at the advanced phase when treatment is restricted to the systemic therapy and multi-kinase inhibitors which are combined with side effects $[15,16]$. So, we are in a critical need for characterization of the molecular mechanistic targets in HCC and tumor-specific signaling pathways, which are still a major goal of $\mathrm{HCC}$ research, to diagnose and treat it at the early stage.

Also, it was shown that human genetic variations such as genetic mutation, single nucleotide polymorphism (SNP), copy number variation (CNV) affect the susceptibility to liver cancer and carcinogenesis $[17,18]$.

Copy number variations have been discovered as intraspecies alterations, which occurs as a repeating of a sequence of nucleotides in tandem multiple times in an individual's genome, including insertion (gain) or deletion (loss) of genetic material with a highly significant biological role; they range in the human genome from $10 \mathrm{~kb}$ to $1 \mathrm{Mb}$ in size and cover about $12 \%$ of the human genome $[19,20]$. These CNVs can change the gene structure and gene expression and lead to significant phenotypic variation [21]. Many studies have reported a critical role for CNVs in important molecular mechanisms of pathogenesis in autoimmune diseases and infectious diseases [22-25].

The previous studies identified that several genes involved in many diseases exhibit CNV such as CYP2D6, MMP-6, BCL9, and BCL9L; these CNVs can be considered as prognostic biomarkers for many diseases [2631]. CN gains on $1 q, 8 q$, and $20 q$ and losses on $1 p, 8 p$, $4 q, 13 q, 16 q$, and $17 p$ have been previously recognized in HCC [32-34].

The human Bcell CLL/lymphoma 9 (BCL9) gene, located at chromosome 1q21, was discovered as an overexpressed gene in a precursor B cell acute lymphoblastic leukemia cell line with $\mathrm{t}(1 ; 14)(\mathrm{q} 21 ; \mathrm{q} 32)$ translocation [35]. It was found that BCL9 is an essential co-activator in the $W n t / \beta$-catenin signaling pathway, enhances $\beta$-catenin-mediated transcription activity, and increases cell proliferation, invasion, migration, and metastatic potential of tumor cell [36,37].

BCL9 has an oncogenic function as it is overexpressed in many solid tumors including HCC and colorectal cancer; this is combined with a poor prognosis of HCC cases [38-40]. Previous studies have examined the role of BCL9 in cancer, including HCC $[27,30,41]$. A copy number gain on 1q is frequently observed in HCC; the BCL9 regional chromosomal gain represents a primary mechanism in the activation of proto-oncogenes during HCC progression [27, 28, 33]. The prognostic significance of BCL9 in HCC remains uncertain. However, in hepatocellular tumors, the deletion of BCL9 increased survival rates, reduced liver size and cell proliferation, decreased expression of Wnt target genes, and inhibited the HCC migration and invasion [30, 41, 42]. So, BCL9 can be the center stage in the HCC treatment.

In the studies of $\mathrm{HCC}$, the role of BCL9 expression has not been characterized especially in Egypt. Therefore, in the present study, we evaluated BCL9 CNV by qPCR in order to elucidate the prognostic significance of BCL9 in HCC-infected patients with clinopathological characteristics.

\section{Methods}

\section{Study population}

A total of 50 patients were enrolled in the present study including (25 HCC-infected patients in the early stage and $25 \mathrm{HCC}$ infected patients in the last stage). All cases were gathered from the National Hepatology and Tropical Medicine Research Institute, Cairo, Egypt, between December 2019 and April 2020. Subjects who had coinfection with HBV, HIV, EBV, CMV, bilharziasis, diabetes mellitus, autoimmune diseases, and other cancers and also had a history of alcohol consumption were excluded from the study.

This study was approved by the Ethics committee of the Medical Research, registration number (17122), National Research Centre, Dokki, Cairo, Egypt, and all participants signed the patient's concept form for this research. Fibrosis was assessed by FIB4 score. Some patients had a biopsy report assessed by Metavir. This study was approved by the local research ethics committee, and written informed consent was obtained from all participants in this study.

\section{Blood collection and plasma separation}

Collect about $10 \mathrm{ml}$ peripheral blood in EDTA tubes, then centrifuge the tubes immediately at $3000 \mathrm{rpm}$ for $10 \mathrm{~min}$, at room temperature, then at 14,000 rpm for 15 $\min$ at $4{ }^{\circ} \mathrm{C}$. Finally, transfer the supernatant plasma into 2 - $\mathrm{ml}$ tubes and preserve them at once at $-80^{\circ} \mathrm{C}$ until further use.

\section{Circulating-free DNA extraction}

Circulating-free DNA (cfDNA) was isolated from the frozen plasma using the QIAamp Circulating Nucleic Acid Kit (Qiagen\#55114) following the manufacturer's instructions and store at $-20^{\circ} \mathrm{C}$ for genetic determination. The concentration of the purified cfDNA was determined by NanoDrop ${ }^{\mathrm{TM}}$ One/OneC Microvolume UV-Vis Spectrophotometer (Catalog number: 701-058108, Thermo Fisher Scientific, Invitrogen).

\section{Measurement of BCL9 copy number}

The copy number variations were determined by using Real-Time Quantitative PCR [43, 44]. The copy number of the BCL9 gene was measured in each cfDNA 
sample using the Mx3000p comparative quantitative PCR system (Agilent Technologies, Germany) and TaqMan copy number assay. TaqMan $\mathrm{CN}$ assay is a duplex experiment using The $\mathrm{FAM}^{\mathrm{TM}}$ dye-labeled TaqMan ${ }^{\circledR}$ Copy Number Target Assay for BCL9 (Assay id:Hs00964453_cn, Cat. No. 4400291, Applied Biosystem, USA), with the VIC ${ }^{\circledR}$ dye-labeled TaqMan ${ }^{\circledR}$ Copy Number Reference Assay for RNase P (RPPH1) (Assay id:4403326, Applied Biosystem, USA) in the same well to quantity small fold changes. The quantitative polymerase chain reaction (qPCR) was carried out in 20 $\mu \mathrm{l}$ volume using $10 \mu \mathrm{l}(2 \times)$ TaqMan genotyping master mix (Applied Biosystem, USA), $1 \mu \mathrm{l}(20 \times)$ TaqMan copy number reference assay RNase $P$ (RPPH1) as an internal control (Assay id:4403326, Applied Biosystem, USA), $1 \mu \mathrm{l}(20 \times)$ Target BCL9 copy number assay (Assay id:Hs00964453_cn, Cat. No. 4400291, Applied Biosystem, USA), $4 \mu \mathrm{l}$ cfDNA sample $(5 \mathrm{ng} / \mu \mathrm{l}$ concentration), and complete the reaction volume with DNAse-free water (Promega, USA). TaqMan target $\mathrm{CN}$ assay and TaqMan ${ }^{\circledR}$ Copy Number Reference Assay are in the same well to quantity small fold changes. All assays were performed in triplicates of each sample and a calibrator sample (healthy sample) and negative control (with water instead of cfDNA sample) in 96-well PCR plate for amplification, using the following program: $95{ }^{\circ} \mathrm{C}$ for $10 \mathrm{~min}$ as the initial melting, followed by 40 cycles at $95^{\circ} \mathrm{C}$ for $15 \mathrm{~s}$ and $60^{\circ} \mathrm{C}$ for $1 \mathrm{~min}$.

The copy number was calculated by the $\Delta \Delta \mathrm{Ct}$ method [45] to obtain the relative quantity (RQ) then multiply it by the copy number of the calibrator, which in this case are 2 .

\section{Statistical analysis}

The statistical analysis was performed using the Social Sciences (SPSS) version 26 (IBM Corp., Armonk, NY, USA). Data were summarized using a median and interquartile range in normally quantitative data, using mean \pm standard deviation in non-normally distributed data, and using frequency (count) and relative frequency (percentage) for categorical data. Comparison between the distributions of categorical variables was performed using the chi-square $\left(\chi^{2}\right)$ method, and comparisons between quantitative variables were done using the non-parametric Kruskal-Wallis test. Moreover, variables were described as odds ratio (OR) with 95\% confidence interval $(95 \% \mathrm{CI})$ by using crosstabs and binary logistic regression analysis. All $P$-values were 2 -sided, and $P$-values less than 0.05 were considered as statistically significant and less than 0.01 were considered highly significant.

\section{Results}

Demographic data and clinical investigation of the study population and Association of HCC characteristics and baseline parameters with HCC development

The demographic, biochemical, virological, and histopathological data of all $50 \mathrm{HCV}$-related HCC-infected patients are summarized in Table 1. Patients have a mean age of 63.14 with $78 \%$ of males, about $84 \%$ of patients have higher AFP, and all patients were cirrhotic. Fifty percent of patients were at the early stage, and the other $50 \%$ were at the late stage, the majority of patients have child score class B, patent portal vein, and no ascites.

Univariate analysis of our data in Table 1 showed that there was a highly statistically significant difference between the two groups (early and late HCC patients) in gender, BCLC, bilharziasis, performance status, child score class, child grade, focal lesion size, portal vein and ascites, and creatinine. Ninety-six percent of late HCC patients were males, about half of late HCC patients (56\%) had enlarged liver in size; on the contrary, half of early HCC patients (56\%) had an average liver. Also, it was found that all early HCC patients had no thrombosed portal vein $(0.00 \%)$ and $92 \%$ of them had no ascites.

\section{Variation of copy number of BCL9 in male versus female HCC patients}

Among our studied population of $\mathrm{HCC}$ patients, CNV was detected and represented by the gain in BCL9 gene in $14 \%$ of patients and all of them were males as in Fig. 1, and $\mathrm{CNV}$ gain was not documented in female HCC patients. CNV frequencies in the BCL9 gene are outlined in Table 2.

\section{Correlation of CNV in the BCL9 gene in HCC patients with HCC development}

CNV in the BCL9 gene showed differential distribution within early and late HCC patients as shown in Table 3. The distribution of gain within early and late HCC individuals was $12 \%$ and $16 \%$, respectively, so it was noticed that the ratio of gain in BCL9 copy number in late individuals was about 1.5 times than that in early HCC individuals.

\section{Correlation between variation in the $\mathrm{BCL} 9$ gene $\mathrm{CN}$ in male patients and the clinical characteristics of HCC patients}

The differential alteration was seen in clinical and HCC characteristics parameters according to CNV in the BCL9 gene as outlined in Table 4. This difference did not reach a significant association in all studied parameters; our results showed that $57 \%$ of those carrying gain in $\mathrm{CNV}$ were at an advanced stage of $\mathrm{HCC}$ 
Table 1 Demographic and clinical parameters of the early versus late HCC patients

\begin{tabular}{|c|c|c|c|c|c|c|c|c|}
\hline \multirow[t]{2}{*}{ Parameters } & & & \multirow{2}{*}{$\begin{array}{l}\text { HCC patients, } \\
N=50\end{array}$} & \multicolumn{2}{|l|}{ HCC stage } & \multirow[t]{2}{*}{ OR $(95 \% \mathrm{Cl})$} & \multirow{2}{*}{$\begin{array}{l}\text { Chi- } \\
\text { square }\end{array}$} & \multirow[t]{2}{*}{$P$-value } \\
\hline & & & & $\begin{array}{l}\text { Early stage, } \\
N=25\end{array}$ & $\begin{array}{l}\text { Late stage, } \\
N=25\end{array}$ & & & \\
\hline \multirow{3}{*}{$\begin{array}{l}\text { Demographic } \\
\text { data }\end{array}$} & \multicolumn{2}{|c|}{ Age (mean $\pm S D$ ), years } & $63.14 \pm 7.89$ & $64.00 \pm 8.54$ & $62.28 \pm 7.25$ & $0.972(0.903-1.045)$ & 1.001 & 0.317 \\
\hline & \multicolumn{2}{|l|}{ Gender, male, no. (\%) } & 39 (78.0\%) & $15(60.0 \%)$ & $24(96.0 \%)$ & $0.063(0.007-0.539)$ & 9.441 & $0.002^{* *}$ \\
\hline & \multicolumn{2}{|c|}{$\mathrm{BMI}($ mean $\pm \mathrm{SD}), \mathrm{kg} / \mathrm{m}^{2}$} & $25.75 \pm 3.58$ & $26.15 \pm 3.96$ & $25.36 \pm 3.20$ & $0.938(0.799-1.102)$ & 0.475 & 0.491 \\
\hline \multirow{11}{*}{$\begin{array}{l}\text { Laboratory inves- } \\
\text { tigation }\end{array}$} & \multirow{2}{*}{$\begin{array}{l}\text { Anti-bilharzial } \\
\text { treatment }\end{array}$} & Yes & $15(30.0 \%)$ & $4(16.0 \%)$ & $11(44.0 \%)$ & \multirow[t]{2}{*}{$0.242(0.064-0.916)$} & \multirow[t]{2}{*}{4.667} & \multirow[t]{2}{*}{$0.031^{*}$} \\
\hline & & No & $35(75.0 \%)$ & $21(84.0 \%)$ & $14(56.0 \%)$ & & & \\
\hline & \multicolumn{2}{|l|}{$\mathrm{Hb}($ mean $\pm \mathrm{SD}), \mathrm{g} / \mathrm{dl}$} & $12.76 \pm 1.83$ & $13.08 \pm 1.15$ & $12.46 \pm 2.30$ & $0.816(0.585-1.138)$ & 2.724 & 0.099 \\
\hline & \multicolumn{2}{|c|}{ TLC (mean \pm SD), 103/mm³ } & $5.54 \pm 2.33$ & $5.17 \pm 1.77$ & $5.91 \pm 2.76$ & $1.155(0.896-1.490)$ & 0.462 & 0.497 \\
\hline & \multicolumn{2}{|c|}{$\mathrm{PLT}($ mean $\pm \mathrm{SD}), 103 / \mathrm{mm}^{3}$} & $140.54 \pm 68.14$ & $132.24 \pm 61.83$ & $148.84 \pm 74.25$ & $1.004(0.995-1.012)$ & 0.502 & 0.479 \\
\hline & \multicolumn{2}{|l|}{ AST (mean \pm SD), U/I } & $44.0(34.0-77.0)$ & $43.0(36.0-64.0)$ & $52.0(34.0-82.0)$ & $1.004(0.986-1.022)$ & 0.115 & 0.734 \\
\hline & \multicolumn{2}{|l|}{$\mathrm{ALT}$ (mean $\pm \mathrm{SD}$ ), $\mathrm{U} / \mathrm{I}$} & $39.0(30.0-59.0)$ & $38.0(30.0-54.0)$ & $48.0(32.0-60.0)$ & $1.007(0.988-1.026)$ & 0.780 & 0.377 \\
\hline & \multicolumn{2}{|c|}{ Bil.T (mean \pm SD), mg/dl } & $1.0(0.8-1.4)$ & $1.0(0.7-1.3)$ & $1.0(0.9-1.6)$ & $1.426(0.521-3.907)$ & 0.870 & 0.351 \\
\hline & \multirow[t]{2}{*}{ AFP, no. (\%) } & $<4.5$ & $8(16.0 \%)$ & $3(12.0 \%)$ & $5(20 \%)$ & \multirow[t]{2}{*}{$1.000(0.998-1.001)$} & \multirow[t]{2}{*}{0.122} & \multirow[t]{2}{*}{0.702} \\
\hline & & $\geq 4.5$ & $42(84.0 \%)$ & $22(88.0 \%)$ & $20(80 \%)$ & & & \\
\hline & Creat (mean \pm SD), & $\mathrm{mg} / \mathrm{dl}$ & $1.01 \pm 0.30$ & $0.86 \pm 0.19$ & $1.15 \pm 0.32$ & $0.964(0.623-1.489)$ & 10.960 & $0.001^{* *}$ \\
\hline HCC character- & $\mathrm{BCLC}$ & 0 & $10(20.0 \%)$ & $10(40.0 \%)$ & $0(0.0 \%)$ & - & 50.000 & $0.001^{* *}$ \\
\hline & & A & 15 (30.0\%) & 15 (60.0\%) & $0(0.0 \%)$ & & & \\
\hline & & C & $21(42.0 \%)$ & $0(0.0 \%)$ & $21(84.0 \%)$ & & & \\
\hline & & $\mathrm{D}$ & $4(8.0 \%)$ & $0(0.0 \%)$ & $4(16.0 \%)$ & & & \\
\hline & F.H of HCC & Yes & $8(16.0 \%)$ & $4(16.0 \%)$ & $4(16.0 \%)$ & $1.000(0.220-4.536)$ & 0.000 & 1.000 \\
\hline & & No & $42(84.0 \%)$ & $21(84.0 \%)$ & $21(28.0 \%)$ & & & \\
\hline & Performance status & 0 & $32(64.0 \%)$ & 25 (100.0\%) & $7(28.0 \%)$ & $0.242(0.1333-0.443)$ & 25.758 & $0.001^{* *}$ \\
\hline & & $<1$ & $1(2.0 \%)$ & $0(0.0 \%)$ & $1(4.00 \%)$ & & & \\
\hline & & $>1$ & 17 (34.0\%) & $0(0.0 \%)$ & $17(68.0 .0 \%)$ & & & \\
\hline & Liver size & Average & $24(48.0 \%)$ & $14(56.0 \%)$ & $10(40.0 \%)$ & - & 2.087 & 0.352 \\
\hline & & Enlarged & $23(46.0 \%)$ & $9(36.0 \%)$ & $14(56.0 \%)$ & & & \\
\hline & & Shrunken & $3(6.0 \%)$ & $2(8.0 \%)$ & $1(4.0 \%)$ & & & \\
\hline & Child score & A & $36(72.0 \%)$ & $24(96.0 \%)$ & $12(48.0 \%)$ & $26.000(3.032-222.928)$ & 14.286 & $0.001^{* *}$ \\
\hline & & B & $14(28.0 \%)$ & $1(4.0 \%)$ & $13(52.0 \%)$ & & & \\
\hline & Child grade & & $5.92 \pm 0.57$ & $5.36 \pm 0.57$ & $6.48 \pm 1.19$ & $3.817(1.691-8.615)$ & 12.585 & $<0.001^{* *}$ \\
\hline & Number of focal & Single & $30(60.0 \%)$ & $14(56.0 \%)$ & $16(64.0 \%)$ & $0.716(0.230-2.230)$ & 3.406 & 0.182 \\
\hline & lesions & Multiple & $20(40.0 \%)$ & $11(44.0 \%)$ & $9(36.0 \%)$ & & & \\
\hline & Focal lesion size & & $3.45(2.00-5.90)$ & $2.24 \pm 0.85$ & $6.33 \pm 3.64$ & $3.103(1.569-6.135)$ & 21.677 & $<0.001^{* *}$ \\
\hline & P.V. & Patent & 42 (84.0\%) & 25 (100.0\%) & $17(66.0 \%)$ & $0.405(0.280-0.584)$ & 9.524 & $0.002^{* *}$ \\
\hline & & Thrombosed & $8(16.0 \%)$ & $0(0.0 \%)$ & $8(32.0 \%)$ & & & \\
\hline & Ascites & Yes & $11(22.0 \%)$ & $2(8.0 \%)$ & $9(36.0 \%)$ & $0.155(0.029-0.813)$ & 5.711 & $0.017^{*}$ \\
\hline & & No & 39 (78.0\%) & $23(92.0 \%)$ & $16(64.0 \%)$ & & & \\
\hline & Cirrhosis, no. (\%) & & $50(100 \%)$ & $25(50 \%)$ & $25(50 \%)$ & & & \\
\hline
\end{tabular}

The data were analyzed by the non-parametric Kruskal-Wallis and chi-square tests

$B M I$ body mass index, HB hemoglobin, TLC total leukocyte count, $P L T$ platelet, $A S T$ aspartate aminotransferase, $A L T$ alanine transferase, Bili $T$ bilirubin total, $A F P$ alphafetoprotein, Creat creatinine, BCLC Barcelona Clinic Liver Cancer, F.H family history, P.V portal vein, OR odds ratio, $C l$ confidence interval

${ }^{*} P$-value $\leq 0.05$ significant

**P-value $\leq 0.01$ highly significant

(BCLC stage C). The frequency of family history of HCC in males within CNV gain HCC patients was few (14.29\%).

Also, the frequencies of performance status $>1$, average and enlarged liver, focal lesion size, and thrombosed portal vein were higher in male patients having BCL9 $\mathrm{CN}$ gain.

Although there was no statistical significance between gain in CN of BCL9 and AFP, the majority of patients (about $85 \%$ ) who have CNV gain have higher AFP values. 


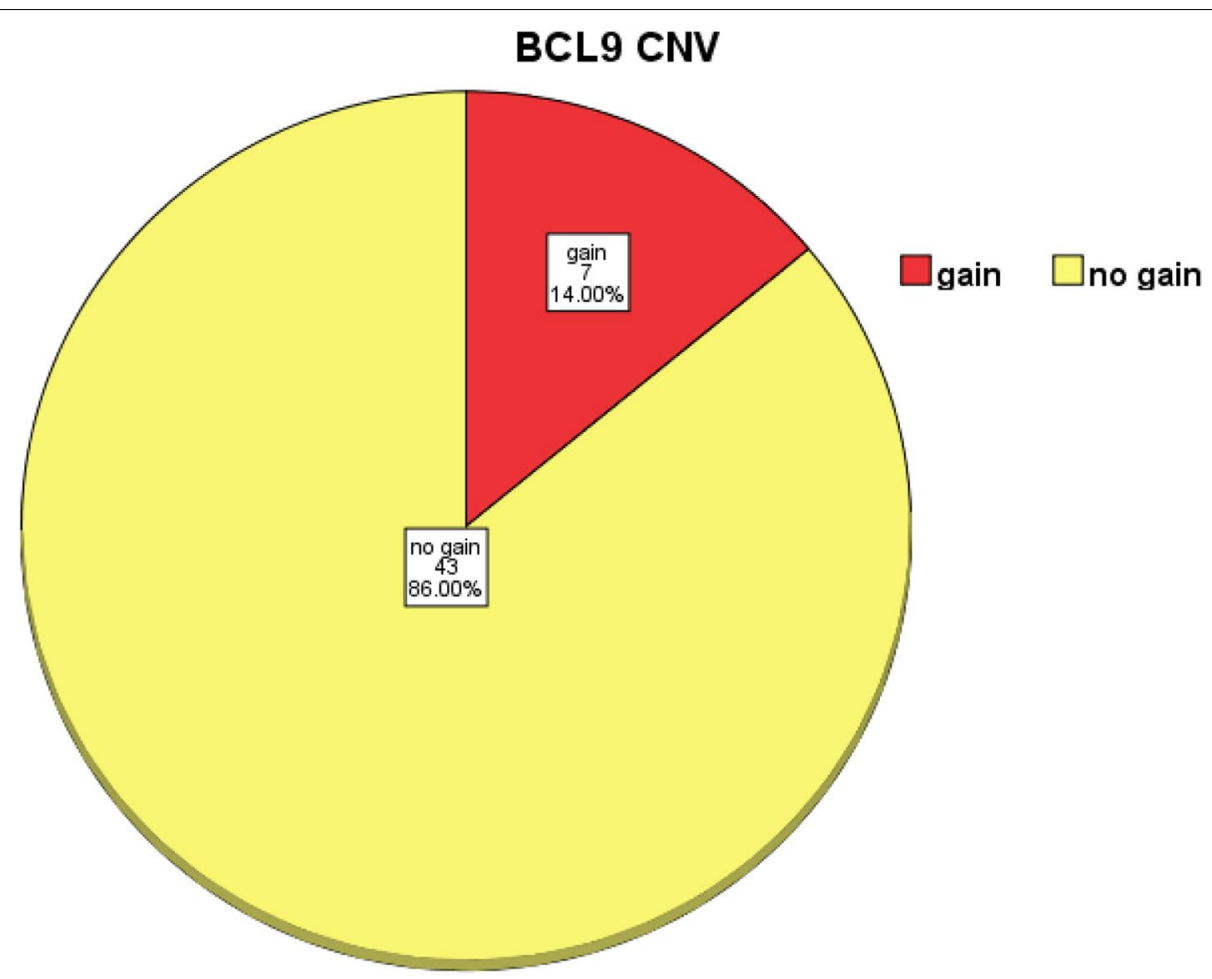

Fig. 1 Pie chart of distribution of BCL9 CNV in HCC patients. The figure shows the copy number distribution of the BCL9 gene. Seven HCC patients $(14 \%)$ had gain in BCL9 CN, and 43 patients (86\%) had no gain in BCL9 CN. Gain: CN gain, no. =7, \% = 14; no gain: no gain in CN, no. = 43, $\%=86$

Table 2 Distribution of CNV in HCC patients

\begin{tabular}{lllll}
\hline CNV & $\begin{array}{l}\text { All HCC } \\
\text { patients, } \\
\boldsymbol{N}=\mathbf{5 0}\end{array}$ & $\begin{array}{l}\text { Male patients, } \\
\boldsymbol{n}=\mathbf{3 9}\end{array}$ & $\begin{array}{l}\text { Female } \\
\text { patients, } \\
\boldsymbol{n}=\mathbf{1 1}\end{array}$ & $\boldsymbol{P}$-value \\
\hline Gain & $7(14 \%)$ & $7(17.95 \%)$ & $0(0 \%)$ & 0.324 \\
No gain & $43(86 \%)$ & $32(82.05 \%)$ & $11(100 \%)$ & \\
\hline
\end{tabular}

CNV copy number variation

Table 3 BCL9 CN gain in HCC patients according to early and late HCC stages

\begin{tabular}{|c|c|c|c|}
\hline CNV & $\begin{array}{l}\text { Early HCC patients, } \\
N=25\end{array}$ & $\begin{array}{l}\text { Late HCC patients, } \\
n=25\end{array}$ & $P$-value \\
\hline Gain & $3(12.0 \%)$ & $4(16.0 \%)$ & 1.00 \\
\hline No gain & 22 (88.0\%) & $21(84.0 \%)$ & \\
\hline
\end{tabular}

Additionally, AST and ALT values were higher in the $\mathrm{CNV}$ gain group.

\section{Discussion}

HCC is considered the most common primary liver cancer, it accounts for about $90 \%$ of cases, which develops mostly in the setting of chronic liver disease $[3,46]$.
There is gender variation of $\mathrm{HCC}$ incidence; as in this current study, $78 \%$ of HCC cases were males, and this agrees with the previous studies which showed that HCC predominantly is more common in males [11, 47]. The strongest risk factor for HCC development is cirrhosis, about $80 \%$ of HCCs develop in the cirrhotic liver [48-50]. Here, we found that all patients have a cirrhotic liver.

The prognosis of patients with this tumor remains poor [50]. Progression pattern may be a key prognostic parameter and important pattern for the fate of HCC, and the performance of histological biomarkers with clinical data has shown promise for surveillance and early diagnosis [1]. In this study, our results showed a highly significant correlation between stages of HCC groups (early and late HCC) and gender, bilharziasis, performance status, child score and grade, focal lesion size, portal vein, and ascites. Our results showed that most of our late HCC patients had enlarged liver, while our early HCC patients group lacks thrombosed portal vein and ascites, this is consistent with previous reports [51-55]. Also, these results are in line with the results of Hyeon et al., who confirmed that tumor stage, tumor recurrence, and survival were significantly associated with larger tumor size, higher Edmondson grade, microvascular invasion, major 
Table 4 BCL9 CN gain according to male gender and clinical and HCC characteristics parameters

\begin{tabular}{|c|c|c|c|c|c|}
\hline \multirow[t]{2}{*}{ Parameters } & & \multirow{2}{*}{$\begin{array}{l}\text { Total male patients, } \\
N=39\end{array}$} & \multicolumn{2}{|c|}{ CNV in male patients } & \multirow[t]{2}{*}{$P$-value } \\
\hline & & & Gain, $N=7$ & No gain, $N=32$ & \\
\hline \multicolumn{2}{|l|}{ Age (mean $\pm S D$ ), years } & $62.64 \pm 8.34$ & $64.00 \pm 5.69$ & $62.34 \pm 8.86$ & 0.761 \\
\hline \multicolumn{2}{|l|}{$\mathrm{BMI}($ mean $\pm \mathrm{SD}), \mathrm{kg} / \mathrm{m}^{2}$} & $25.0 \pm 3.10$ & $23.57 \pm 3.02$ & $25.32 \pm 3.08$ & 0.212 \\
\hline \multicolumn{2}{|l|}{$\mathrm{Hb}($ mean $\pm \mathrm{SD}), \mathrm{g} / \mathrm{dl}$} & $12.73 \pm 1.97$ & $12.90 \pm 2.04$ & $12.69 \pm 1.99$ & 0.707 \\
\hline \multicolumn{2}{|l|}{ TLC (mean \pm SD), 103/mm³ } & $5.60 \pm 2.52$ & $5.08 \pm 1.75$ & $5.72 \pm 2.67$ & 0.654 \\
\hline \multicolumn{2}{|l|}{$\mathrm{PLT}($ mean $\pm \mathrm{SD}), 103 / \mathrm{mm}^{3}$} & $141.82 \pm 69.38$ & $143.71 \pm 64.76$ & $141.41 \pm 71.33$ & 0.629 \\
\hline \multicolumn{2}{|l|}{ AST (mean \pm SD), U/I } & $55.15 \pm 33.77$ & $66.86 \pm 42.98$ & $52.59 \pm 31.67$ & 0.484 \\
\hline \multicolumn{2}{|l|}{$\mathrm{ALT}($ mean $\pm \mathrm{SD}), \mathrm{U} / \mathrm{I}$} & $49.26 \pm 35.31$ & $55.0 \pm 26.64$ & $48.00 \pm 37.1$ & 0.287 \\
\hline \multicolumn{2}{|l|}{ Bil.T (mean \pm SD), mg/dl } & $1.15 \pm 0.52$ & $1.07 \pm 0.50$ & $1.17 \pm 0.53$ & 0.603 \\
\hline \multirow[t]{2}{*}{ AFP, no. (\%) } & $<4.5$ & $5(12.82 \%)$ & $1(14.29 \%)$ & $4(12.50 \%)$ & 1.000 \\
\hline & $\geq 4.5$ & $34(87.18 \%)$ & $6(85.71 \%)$ & $28(87.5 \%)$ & \\
\hline \multirow[t]{4}{*}{$\mathrm{BCLC}$} & 0 & $6(15.38 \%)$ & $1(14.29 \%)$ & $5(15.6 \%)$ & 0.929 \\
\hline & A & $9(23.08 \%)$ & $2(28.57 \%)$ & $7(21.87 \%)$ & 0.653 \\
\hline & C & $20(51.28 \%)$ & $4(57.14 \%)$ & $16(50.0 \%)$ & 0.732 \\
\hline & $\mathrm{D}$ & $4(10.26 \%)$ & $0(0.0 \%)$ & $4(12.5 \%)$ & 0.323 \\
\hline \multirow[t]{2}{*}{ F.H of HCC } & Yes & $6(15.38 \%)$ & $1(14.29 \%)$ & $5(15.63 \%)$ & 1.00 \\
\hline & No & $33(84.62 \%)$ & $6(85.71 \%)$ & $27(84.37 \%)$ & \\
\hline \multirow[t]{3}{*}{ Performance status } & 0 & $22(56.41 \%)$ & $3(42.86 \%)$ & $19(59.38 \%)$ & 0.426 \\
\hline & $<1$ & $1(2.56 \%)$ & $0(0.0 \%)$ & $1(3.12 \%)$ & 0.636 \\
\hline & $>1$ & $16(41.03 \%)$ & $4(57.14 \%)$ & $12(37.5 \%)$ & 0.339 \\
\hline \multirow[t]{3}{*}{ Liver size } & Average & $18(46.15 \%)$ & $4(57.14 \%)$ & $14(43.75 \%)$ & 0.520 \\
\hline & Enlarged & $18(46.15 \%)$ & $3(42.86 \%)$ & $15(46.88 \%)$ & 0.847 \\
\hline & Shrunken & $3(7.70 \%)$ & $0(0.0 \%)$ & $3(9.37 \%)$ & 0.399 \\
\hline \multirow[t]{2}{*}{ Child score } & A & $26(66.67 \%)$ & $4(57.14 \%)$ & $22(68.75 \%)$ & 0.666 \\
\hline & B & $13(33.33 \%)$ & $3(42.86 \%)$ & $10(31.25 \%)$ & \\
\hline \multicolumn{2}{|l|}{ Child grade } & $6.08 \pm 1.13$ & $6.0 \pm 1.0$ & $6.09 \pm 1.17$ & 0.957 \\
\hline \multirow[t]{2}{*}{ No. of focal lesions } & Single & $23(58.97 \%)$ & $5(71.43 \%)$ & $18(56.25 \%)$ & 1.00 \\
\hline & Multiple & $16(41.03 \%)$ & $2(28.57 \%)$ & $14(43.75 \%)$ & \\
\hline \multicolumn{2}{|l|}{ Focal lesion size } & $4.83 \pm 3.46$ & $5.86 \pm 4.85$ & $4.60 \pm 3.14$ & 0.707 \\
\hline \multirow[t]{2}{*}{ P.V. } & Patent & $7(17.95 \%)$ & $2(28.57 \%)$ & $5(15.63 \%)$ & 0.588 \\
\hline & Thrombosed & $32(82.05 \%)$ & $5(71.43 \%)$ & $27(84.37 \%)$ & \\
\hline \multirow[t]{2}{*}{ Ascites } & Yes & $9(23.08 \%)$ & $2(28.57 \%)$ & $7(21.87 \%)$ & 0.653 \\
\hline & No & $30(76.92 \%)$ & $5(71.43 \%)$ & $25(78.13 \%)$ & \\
\hline
\end{tabular}

The data were analyzed by the non-parametric Kruskal-Wallis and chi-square tests.

*P-value $\leq 0.05$ significant

**P-value $\leq 0.01$ highly significant

portal vein, higher BCLC grade, higher AFP, liver cirrhosis, and viral etiology [27].

Also, it is known that HCC is a heterogenous pathology, involving many somatic genetic mutations; these genetic alterations and abnormal activation of specific pathology are responsible for HCC development, tumor differentiation, and related clinical outcomes $[6,7,56]$. Copy number $(\mathrm{CN})$ in genomic DNA is one of the most observed genetic alterations and chromosomal instability in $\mathrm{HCC}$ and can be used as an indicator of major disease [31-34, 57].
A gain in 1q chromosome is one of the most frequently detected chromosomal alterations in HCC and has been suggested as an early genomic event in the HCC development [58]. BCL9 is considered one of the important oncogenes located at 1q21.1 and encodes B cell CLL/ lymphoma 9 which is considered as co-activator of $\beta$-catenin-mediated transcription in the $\mathrm{Wnt} / \beta$-catenin signaling, and its upregulation plays a vital role in certain cancer development and progression, including colorectal cancer and HCC $[37,38]$. On the other hand, it inhibits tumor growth and increases the survival outcome of 
multiple myeloma and colon cancer through blocking the Wnt/ $\beta$-catenin pathway $[30,41]$. Wang et al. credentialed BCL9 as a candidate driver gene as it plays a significant role in HCC growth and survival and may serve as a potential therapeutic target for the disease treatment, as it found a significant correlation between BCL9 somatic copy number and gene expression in primary HCCs [59]. Also, other studies have examined the role of BCL9 in cancer, including HCC [27, 30, 41, 42].

In this study, we focused on studying the alteration in CN of BCL9 in Egyptian HCC patients as a crucial risk factor in HCC development. To the best of our knowledge, this is the first study to use CN analysis of BCL9 to explore the relation between $\mathrm{CNV}$ and $\mathrm{HCC}$ development, and the role of BCL9 in HCC has not been reported previously in Egypt.

Our results showed variation in $\mathrm{BCl} 9 \mathrm{CN}$ towards gain which was detected in $14 \%$ of our patients; this is in agreement with Wang et al's study which found that BCL9 was highly amplified in $8.7 \%$ of the HCC cohort [59]. Also, we found that all of $\mathrm{CN}$ gain was in male patients; this information has not been discussed before and may be one of the reasons why HCC is more common in males, but this needs more research to confirm this theory.

We further noticed that the ratio of $\mathrm{CN}$ gain in $\mathrm{HCC}$ individuals at the advanced stage was higher than the early stage, and this may reflect the extent of the BCL9 CN prognostic role in HCC development. This matches with other studies which found that somatic CN of BCL9 gene was associated with advanced HCC tumor stage [30, 59, 60].

Here, our results indicated that BCL9 CN gain was associated with the higher performance status, enlarged liver size, higher focal lesion size, and thrombosed portal vein; although this association did not reach the significance, this may lead to that BCL9 CNV might have a role in HCC development, and there was not any significant association between this $\mathrm{CN}$ gain and the other parameters. This is in line with the other studies which suggest the involvement of BCL9 in the HCC pathogenesis and prognosis [27, 30, 61].

An important point was discussed in our results; AFP status was higher in the majority of the BCL9 CN gain group, as AFP is the most common marker for HCC diagnosis [62]; therefore, we speculate that there is a vital role of AFP to be taken into consideration as an influencer with BCL9 CNV in HCC patients, but further work is needed to verify our hypothesis.

\section{Conclusion}

This study is the first to discuss BCL9 CNV in HCC Egyptian patients; it recorded that there is gain in BCL9 $\mathrm{CNV}$ in $14 \%$ of $\mathrm{HCC}$ patients and also showed that $\mathrm{CN}$ gains existed only in male patients. Our finding indicated that CNV of BCL9 did not affect HCC development in our patient cohort, but it was found that gender, bilharziasis, performance status, child score class, child grade, focal lesion size, portal vein, and ascites have correlated with HCC development and prognosis.

\section{Limitations}

One of the main limitations in our work is the lack of healthy individuals to compare BCL9 CNV in HCC patients and healthy individuals. Second is the small sample number enrolled in the current study of Egyptian HCC patients. So, future studies should focus on a large number of HCC patients to confirm our results.

\section{Abbreviations}

HCC: Hepatocellular carcinoma; CN: Copy number; CNV: Copy number variation; BCL9: Bcell CLL/lymphoma 9; HCV: Hepatitis C virus; HBV: Hepatitis B virus; NAFLD: Non-alcoholic fatty liver disease; SNP: Single nucleotide polymorphism; CYP2D6: Cytochrome P450 family 2 subfamily D member 6; MMP-6: Matrix metalloproteinase 6; BCL9L: B cell CLL/lymphoma 9 like; HIV: Human immunodeficiency virus; EBV: Epstein-Barr virus; CMV: Cytomegalovirus; EDTA: Ethylenediaminetetraacetic acid; cfDNA: Circulating-free DNA; QPCR: Quantitative polymerase chain reaction; $R Q$ : Relative quantity; $x^{2}$ : Chi-square; OR: Odds ratio; Cl: Confidence interval; SD: Standard deviation; BCLC: Barcelona Clinic Liver Cancer.

\section{Acknowledgements}

The authors would like to acknowledge the National Research Centre, as well as the National Hepatology and Tropical Medicine Research Institute, Cairo, Egypt, and Microbiology Department, Faculty of Science, Ain-Shams University, Cairo, Egypt, for providing laboratory space, types of equipment, and patient samples for the achievement of the current work.

\section{Authors' contributions}

S.S.Y. designed the research, shared in practical work; analyzed the data; and revised the manuscript. E.A.A. collected the patients'samples, performed the practical work and data analysis, and drafted the manuscript. M.H.B. recruited the patients'samples according to the criteria and did the clinical examination. A.B.B. supervised and contributed to the study and reviewed the manuscript. All authors reviewed the final manuscript.

\section{Funding}

This work was funded by the National Research Centre (NRC) of Egypt and also by the authors (Samar Samir Youssef, Eman Abd El Razek Abbas).

Availability of data and materials

All data generated or analyzed during this study are included in this article.

\section{Declarations}

\section{Ethics approval and consent to participate}

This study was approved by the Medical Research Ethics Committee, the committee's registration number (17122), National Research Centre, El Buhouth St., Dokki, Cairo, Egypt.

All patients signed a written informed consent before inclusion in the study.

\section{Consent for publication}

Not applicable

\section{Competing interests}

The authors declare that they have no competing interests. 


\section{Author details}

'Microbial Biotechnology Department, National Research Centre, 33 El-Buhouth St., Dokki, Giza, Cairo 12622, Egypt. ${ }^{2}$ Microbiology Department, Faculty of Science, Ain-Shams University, Cairo, Egypt. ${ }^{3}$ Tropical Medicine Department, National Hepatology and Tropical Medicine Research Institute, Cairo, Egypt.

\section{Received: 28 August 2021 Accepted: 6 December 2021}

Published online: 03 January 2022

\section{References}

1. Forner A, Reig M, Bruix J (2018) Hepatocellular carcinoma. Lancet (London, England) 391:1301-1314. https://doi.org/10.1016/S0140-6736(18)30010-2

2. Villanueva A (2019) Hepatocellular carcinoma. The New England journal of medicine 380:1450-1462. https://doi.org/10.1056/nejmra1713263

3. Akinyemiju T, Abera S, Ahmed M, Alam N, Alemayohu MA, Allen C, Al-Raddadi R, Alvis-Guzman N, Amoako Y, Artaman A, Ayele TA, Barac A, Bensenor I, Berhane A, Bhutta Z, Castillo-Rivas J, Chitheer A, Choi JY, Cowie B, Dandona L, Dandona R, Dey S, Dicker D, Phuc H, Ekwueme DU, Zaki MS, Fischer F, Fürst T, Hancock J, Hay SI, Hotez P, Jee SH, Kasaeian A, Khader Y, Khang YH, Kumar A, Kutz M, Larson H, Lopez A, Lunevicius R, Malekzadeh R, McAlinden C, Meier T, Mendoza W, Mokdad A, MoradiLakeh M, Nagel G, Nguyen Q, Nguyen G, Ogbo F, Patton G, Pereira DM Pourmalek F, Qorbani M, Radfar A, Roshandel G, Salomon JA, Sanabria J, Sartorius B, Satpathy M, Sawhney M, Sepanlou S, Shackelford K, Shore H, Sun J, Mengistu DT, Topór-Mądry R, Tran B, Ukwaja KN, Vlassov V, Vollset SE, Vos T, Wakayo T, Weiderpass E, Werdecker A, Yonemoto N, Younis M, Yu C, Zaidi Z, Zhu L, Murray CJL, Naghavi M, Fitzmaurice C (2017) The burden of primary liver cancer and underlying etiologies from 1990 to 2015 at the global, regional, and national level: results from the Global Burden of Disease Study 2015. JAMA oncology 3:1683-1691. https://doi.org/10. 1001/jamaoncol.2017.3055

4. Rashed WM, Kandeil MAM, Mahmoud MO, Ezzat S (2020) Hepatocellular carcinoma (HCC) in Egypt: a comprehensive overview. Journal of the Egyptian National Cancer Institute 32:1-11. https://doi.org/10.1186/ s43046-020-0016-x

5. Friemel J, Rechsteiner M, Frick L, Böhm F, Struckmann K, Egger M, Moch $H_{\text {, }}$ Heikenwalder M, Weber A (2015) Intratumor heterogeneity in hepatocelIular carcinoma. Clinical Cancer Research 21:1951-1961. https://doi.org/ 10.1158/1078-0432.ccr-14-0122

6. Lee JM, Yang J, Newell P, Singh S, Parwani A, Friedman SL, Nejak-Bowen KN, Monga SP (2014) $\beta$-Catenin signaling in hepatocellular cancer: implications in inflammation, fibrosis, and proliferation. Cancer letters 343:90-97. https://doi.org/10.1016/j.canlet.2013.09.020

7. Wang Z, Sheng YY, Gao XM, Wang CQ, Wang XY, Lu X, Wei JW, Zhang KL, Dong QZ, Qin LX (2015) $\beta$-catenin mutation is correlated with a favorable prognosis in patients with hepatocellular carcinoma. Molecular and clinical oncology 3:936-940. https://doi.org/10.3892/ mco.2015.569

8. Zhao C, Nguyen MH (2016) Hepatocellular carcinoma screening and surveillance. Journal of clinical gastroenterology 50:120-133. https://doi. org/10.1097/mcg.0000000000000446

9. Ibrahim AS, Khaled HM, Mikhail NN, Baraka H, Kamel H (2014) Cancer incidence in Egypt: results of the national population-based cancer registry program. Journal of cancer epidemiology 2014. https://doi.org/10.1155/ 2014/437971

10. Ziada DH, El Sadany S, Soliman H, Abd-Elsalam S, Salama M, Hawash N, Selim A, Hamisa M, Elsabagh HM (2016) Prevalence of hepatocellular carcinoma in chronic hepatitis C patients in Mid Delta, Egypt: a single center study. Journal of the Egyptian National Cancer Institute 28:257-262. https://doi.org/10.1016/j.jnci.2016.06.001

11. Ferlay J, Soerjomataram I, Dikshit R, Eser S, Mathers C, Rebelo M, Parkin DM, Forman D, Bray F (2015) Cancer incidence and mortality worldwide: sources, methods and major patterns in GLOBOCAN 2012. International journal of cancer 136:E359-E386. https://doi.org/10.1002/ ijc.29210

12. Jemal A, Bray F, Center MM, Ferlay J, Ward E, Forman D (2011) Global cancer statistics. CA: a cancer journal for clinicians 61:69-90. https://doi. org/10.3322/caac.20107
13. Torre LA, Bray F, Siegel RL, Ferlay J, Lortet-Tieulent J, Jemal A (2015) Global cancer statistics, 2012. CA: a cancer journal for clinicians 65:87-108. https://doi.org/10.3322/caac.21262

14. Yarchoan M, Agarwal P, Villanueva A, Rao S, Dawson LA, Karasic T, Llovet JM, Finn RS, Groopman JD, El-Serag HB (2019) Recent developments and therapeutic strategies against hepatocellular carcinoma. Cancer research 79:4326-4330. https://doi.org/10.1158/0008-5472.can-19-0803

15. Kudo M, Finn RS, Qin S, Han K-H, Ikeda K, Piscaglia F, Baron A, Park J-W, Han G, Jassem J (2018) Lenvatinib versus sorafenib in first-line treatment of patients with unresectable hepatocellular carcinoma: a randomised phase 3 non-inferiority trial. The Lancet 391:1163-1173. https://doi.org/ 10.1016/s0140-6736(18)30207-1

16. Llovet JM, Ricci S, Mazzaferro V, Hilgard P, Gane E, Blanc J-F, De Oliveira AC, Santoro A, Raoul J-L, Forner A (2008) Sorafenib in advanced hepatocellular carcinoma. New England journal of medicine 359:378-390. https://doi. org/10.1056/nejmoa0708857

17. Li J-F, Zheng E-Q, Xie M (2019) Association between rs738409 polymorphism in patatin-like phospholipase domain-containing protein 3 (PNPLA3) gene and hepatocellular carcinoma susceptibility: evidence from case-control studies. Gene 685:143-148. https://doi.org/10.1016/j. gene.2018.11.012

18. Nahon P, Zucman-Rossi J (2012) Single nucleotide polymorphisms and risk of hepatocellular carcinoma in cirrhosis. Journal of hepatology 57:663-674. https://doi.org/10.1016/j.jhep.2012.02.035

19. Inaki K, Liu ET (2012) Structural mutations in cancer: mechanistic and functional insights. Trends in Genetics 28:550-559. https://doi.org/10. 1016/j.tig.2012.07.002

20. Nowakowska B (2017) Clinical interpretation of copy number variants in the human genome. Journal of applied genetics 58:449-457. https://doi. org/10.1007/s13353-017-0407-4

21. Itsara A, Cooper GM, Baker C, Girirajan S, Li J, Absher D, Krauss RM, Myers RM, Ridker PM, Chasman DI (2009) Population analysis of large copy number variants and hotspots of human genetic disease. The American Journal of Human Genetics 84:148-161. https://doi.org/10.1016/j.ajhg. 2008.12.014

22. Beeghly-Fadiel A, Lu W, Shu X-O, Long J, Cai Q, Xiang Y, Gao Y-T, Zheng W (2011) MMP9 polymorphisms and breast cancer risk: a report from the Shanghai Breast Cancer Genetics Study. Breast cancer research and treatment 126:507-513. https://doi.org/10.1007/s10549-010-1119-1

23. Sharma KL, Misra S, Kumar A, Mittal B (2012) Higher risk of matrix metalloproteinase (MMP-2, 7, 9) and tissue inhibitor of metalloproteinase (TIMP-2) genetic variants to gallbladder cancer. Liver International 32:1278-1286. https://doi.org/10.1111/j.1478-3231.2012.02822.x

24. Shrestha S, Tang J, Kaslow RA (2009) Gene copy number: learning to count past two. Nature medicine 15:1127-1129. https://doi.org/10.1038/ $\mathrm{nm} 1009-1127$

25. Xue Q, Cao L, Chen XY, Zhao J, Gao L, Li SZ, Fei Z (2017) High expression of MMP9 in glioma affects cell proliferation and is associated with patient survival rates. Oncology letters 13:1325-1330. https://doi.org/10.3892/ol. 2017.5567

26. Bradford LD (2002) CYP2D6 allele frequency in European Caucasians, Asians, Africans and their descendants. Pharmacogenomics 3:229-243. https://doi.org/10.1517/14622416.3.2.229

27. Hyeon J, Ahn S, Lee JJ, Song DH, Park C-K (2013) Prognostic significance of BCL9 expression in hepatocellular carcinoma. Korean journal of pathology 47:130. https://doi.org/10.4132/koreanjpathol.2013.47.2.130

28. Kim TM, Yim SH, Shin SH, Xu HD, Jung YC, Park CK, Choi JY, Park WS, Kwon MS, Fiegler H (2008) Clinical implication of recurrent copy number alterations in hepatocellular carcinoma and putative oncogenes in recurrent gains on 1q. International journal of cancer 123:2808-2815. https://doi. org/10.1002/ijc.23901

29. Sistonen J, Sajantila A, Lao O, Corander J, Barbujani G, Fuselli S (2007) CYP2D6 worldwide genetic variation shows high frequency of altered activity variants and no continental structure. Pharmacogenetics and genomics 17:93-101. https://doi.org/10.1038/srep40446

30. Xu W, Zhou W, Cheng M, Wang J, Liu Z, He S, Luo X, Huang W, Chen T, Yan W (2017) Hypoxia activates Wnt/ $\beta$-catenin signaling by regulating the expression of BCL9 in human hepatocellular carcinoma. Scientific reports 7:1-13. https://doi.org/10.1038/srep40446

31. Yu, X., Huang, J., Wu, S., Huang, Y., Shan, Y., and Lu, C. (2020) Copy number variations of MMP-9 are prognostic biomarkers for 
hepatocellular carcinoma, Translational Cancer Research 9, 698-706. 10.21037/tcr.2019.11.52

32. Hashimoto K, Mori N, Tamesa T, Okada T, Kawauchi S, Oga A, Furuya T, Tangoku A, Oka M, Sasaki K (2004) Analysis of DNA copy number aberrations in hepatitis $\mathrm{C}$ virus-associated hepatocellular carcinomas by conventional CGH and array CGH. Modern Pathology 17:617-622. https:// doi.org/10.1038/modpathol.3800107

33. Moinzadeh P, Breuhahn K, Stützer H, Schirmacher P (2005) Chromosome alterations in human hepatocellular carcinomas correlate with aetiology and histological grade-results of an explorative CGH meta-analysis. British journal of cancer 92:935-941. https://doi.org/10.1038/sj.bjc.6602448

34. Zimonjic DB, Keck CL, Thorgeirsson SS, Popescu NC (1999) Novel recurrent genetic imbalances in human hepatocellular carcinoma cell lines identified by comparative genomic hybridization. Hepatology 29:1208-1214. https://doi.org/10.1002/hep.510290410

35. Wong N, Lai P, Lee S-W, Fan S, Pang E, Liew C-T, Sheng Z, Lau JW-Y, Johnson PJ (1999) Assessment of genetic changes in hepatocellular carcinoma by comparative genomic hybridization analysis: relationship to disease stage, tumor size, and cirrhosis. The American journal of pathology 154:37-43. https://doi.org/10.1016/s0002-9440(10)65248-0

36. De la Roche M, Worm J, Bienz M (2008) The function of BCL9 in Wnt/Bcatenin signaling and colorectal cancer cells. BMC cancer 8:1-13. https:// doi.org/10.1186/1471-2407-8-199

37. Kramps T, Peter O, Brunner E, Nellen D, Froesch B, Chatterjee $S$, Murone M, Züllig S, Basler K (2002) Wnt/wingless signaling requires BCL9/leglessmediated recruitment of pygopus to the nuclear $\beta$-catenin-TCF complex. Cell 109:47-60. https://doi.org/10.1016/s0092-8674(02)00679-7

38. Mani M, Carrasco DE, Zhang Y, Takada K, Gatt ME, Dutta-Simmons J, Ikeda H, Diaz-Griffero F, Pena-Cruz V, Bertagnolli M (2009) BCL9 promotes tumor progression by conferring enhanced proliferative, metastatic, and angiogenic properties to cancer cells. Cancer research 69:7577-7586. https:// doi.org/10.1158/0008-5472.can-09-0773

39. Takada, K., Zhu, D., Bird, G. H., Sukhdeo, K., Zhao, J.-J., Mani, M., Lemieux, M., Carrasco, D. E., Ryan, J., and Horst, D. (2012) Targeted disruption of the BCL9/B-catenin complex inhibits oncogenic Wnt signaling, Science translational medicine 4, 148ra117-148ra117. https://doi.org/10.1126/scitr ansImed.3003808

40. Zhao J-J, Lin J, Zhu D, Wang X, Brooks D, Chen M, Chu Z-B, Takada K, Ciccarelli B, Tao J (2014) miR-30-5p functions as a tumor suppressor and novel therapeutic tool by targeting the oncogenic Wnt/B-catenin/BCL9 pathway. Cancer research 74:1801-1813. https://doi.org/10.1158/00085472.can-13-3311-t

41. Gay DM, Ridgway RA, Müller M, Hodder MC, Hedley A, Clark W, Leach JD, Jackstadt R, Nixon C, Huels DJ (2019) Loss of BCL9/9l suppresses Wnt driven tumourigenesis in models that recapitulate human cancer. Nature communications 10:1-16. https://doi.org/10.1038/s41467-019-08586-3

42. Yang C, Xu Y, Cheng F, Hu Y, Yang S, Rao J, Wang X (2017) miR-1301 inhibits hepatocellular carcinoma cell migration, invasion, and angiogenesis by decreasing Wnt/ $\beta$-catenin signaling through targeting BCL9. Cell death \& disease 8:e2999-e2999. https://doi.org/10.1038/cddis.2017.356

43. Bodin L, Beaune PH, Loriot M-A (2005) Determination of cytochrome P450 2D6 (CYP2D6) gene copy number by real-time quantitative PCR. Journal of Biomedicine and Biotechnology 2005:248-253. https://doi. org/10.1155/JBB.2005.248

44. Nguyen DL, Staeker J, Laika B, Steimer W (2009) TaqMan real-time PCR quantification strategy of CYP2D6 gene copy number for the LightCycler 2.0. Clinica chimica acta 403:207-211. https://doi.org/10.1016/j.cca.2009. 03.007

45. Schmittgen TD, Livak KJ (2008) Analyzing real-time PCR data by the comparative CT method. Nature protocols 3:1101-1108. https://doi.org/ 10.1038/nprot.2008.73

46. McGlynn KA, Petrick JL, El-Serag HB (2021) Epidemiology of hepatocellular carcinoma. Hepatology 73:4-13. https://doi.org/10.1002/hep.31288

47. Omar A, Abou-Alfa GK, Khairy A, Omar H (2013) Risk factors for developing hepatocellular carcinoma in Egypt. Chinese clinical oncology 2. https://doi.org/10.3978/j.issn.2304-3865.2013.11.07

48. Liver EAFTSOT (2018) EASL clinical practice guidelines: management of hepatocellular carcinoma. Journal of hepatology 69:182-236. https://doi. org/10.1016/j.jhep.2018.03.019
49. Llovet JM, Burroughs A, Bruix J (2003) Hepatocellular carcinoma. Lancet (London, England) 362:1907-1917. https://doi.org/10.1016/s01406736(03)14964-1

50. Martínez-Chantar ML, Avila MA, Lu SC (2020) Hepatocellular carcinoma: updates in pathogenesis, detection and treatment. Multidisciplinary Digital Publishing Institute. https://doi.org/10.3390/cancers12102729

51. Cillo U, Vitale A, Grigoletto F, Farinati F, Brolese A, Zanus G, Neri D, Boccagni P, Srsen N, D'Amico F (2006) Prospective validation of the Barcelona Clinic Liver Cancer staging system. Journal of hepatology 44:723-731. https://doi.org/10.1016/j.jhep.2005.12.015

52. Gomaa Al, Hashim MS, Waked I (2014) Comparing staging systems for predicting prognosis and survival in patients with hepatocellular carcinoma in Egypt. PloS one 9:e90929. https://doi.org/10.1371/journal.pone. 0090929

53. Grieco A, Pompili M, Caminiti G, Miele L, Covino M, Alfei B, Rapaccini GL, Gasbarrini G (2005) Prognostic factors for survival in patients with earlyintermediate hepatocellular carcinoma undergoing non-surgical therapy: comparison of Okuda. CLIP, and BCLC staging systems in a single Italian centre, Gut 54:411-418. https://doi.org/10.1136/gut.2004.048124

54. Lee, J. H., Han, S. Y., Jo, J. H., Kim, S. K., Go, B. S., Oh, J. Y., Choi, J. C., Lee, S. W. Jang, J. S., and Roh, M. H. (2007) Prognostic factors for survival in patients with hepatocellular carcinoma after radiofrequency ablation, The Korean journal of gastroenterology= Taehan Sohwagi Hakhoe chi 49, 17-23. https://doi.org/10.4166/kjg.2020.75.1.17

55. Marrero JA, Fontana RJ, Barrat A, Askari F, Conjeevaram HS, Su GL, Lok AS (2005) Prognosis of hepatocellular carcinoma: comparison of 7 staging systems in an American cohort. Hepatology 41:707-715. https://doi.org/ 10.1002/hep.20636

56. Li P, Cao Y, Li Y, Zhou L, Liu X, Geng M (2014) Expression of Wnt-5a and $\beta$-catenin in primary hepatocellular carcinoma. International journal of clinical and experimental pathology 7:3190

57. Bigagli E, De Filippo C, Castagnini C, Toti S, Acquadro F, Giudici F, Fazi M, Dolara P, Messerini L, Tonelli F (2016) DNA copy number alterations, gene expression changes and disease-free survival in patients with colorectal cancer: a 10 year follow-up. Cellular Oncology 39:545-558. https://doi. org/10.1007/s13402-016-0299-z

58. Lau S-H, Guan X-Y (2005) Cytogenetic and molecular genetic alterations in hepatocellular carcinoma. Acta Pharmacologica Sinica 26:659-665. https://doi.org/10.1111/j.1745-7254.2005.00126.x

59. Wang K, Lim HY, Shi S, Lee J, Deng S, Xie T, Zhu Z, Wang Y, Pocalyko D, Yang WJ (2013) Genomic landscape of copy number aberrations enables the identification of oncogenic drivers in hepatocellular carcinoma. Hepatology 58:706-717. https://doi.org/10.1002/hep.26402

60. Huge N, Sandbothe M, Schröder AK, Stalke A, Eilers M, Schäffer V, Schlegelberger B, Illig T, Vajen B, Skawran B (2020) Wnt status-dependent oncogenic role of BCL9 and BCL9L in hepatocellular carcinoma. Hepatology international 14:373-384. https://doi.org/10.1007/ s12072-019-09977-w

61. Moghe A, Monga SP (2020) BCL9/BCL9L in hepatocellular carcinoma: will it or Wnt it be the next therapeutic target? Springer. https://doi.org/10. 1007/s12072-020-10059-5

62. Molparia B, Oliveira G, Wagner JL, Spencer EG, Torkamani A (2018) A feasibility study of colorectal cancer diagnosis via circulating tumor DNA derived CNV detection. PloS one 13:e0196826. https://doi.org/10.1371/ journal.pone.0196826

\section{Publisher's Note}

Springer Nature remains neutral with regard to jurisdictional claims in published maps and institutional affiliations. 